\title{
The Dialogical Subgenres of Argument in British and Ukrainian Lexicographical Presentation: a Comparative Aspect
}

\author{
Olexiy Borysov ${ }^{1}$ \\ ${ }^{1}$ T. H. Shevchenko National University "Chernihiv Kolehium" \\ 53 Hetmana Polubotka, Chernihiv, 14013, Ukraine
}

DOI: $10.22178 /$ pos.39-7

LCC Subject Category:

PE1001-1693, PG3801-3987

Received 01.08.2018

Accepted 15.09.2018

Published online 31.10.2018

Corresponding Author:

neapol.1985@gmail.com

(C) 2018 The Author. This article

is licensed under a Creative

Commons Attribution 4.0 License

(c) (i)

\begin{abstract}
The thesis is devoted to the comparative study of the dialogical genre "argument" in the present-day British and Ukrainian language pictures of the world. This type of investigation has been the first so far in the field of comparative linguistics that deals with human communication. Argument is a widespread type of day-to-day communication, namely a kind of dialogue that finds its verbal conceptualization in English and Ukrainian. The general idea of argument can be formulated as an emotionally coloured verbal communication between partners who differ about something and try to convince each other in the righteousness of one's position. Such a general scheme of argument interpretation is modified in the structures of ethnic languages. Thus, the terms argument and суперечка reflect the existing differences between two nations as for the type of interaction itself. The crucial difference is understanding of argument as a verbal exchange in British society and a verbal contest in Ukrainian one. One more allomorphic feature is that the British typically tend to get excited in argument, the fact reflected in the semantic components a heated or angry interaction. The next verbal specification argument gets in a number of its forms or subgenres. A closer comparative look at such kinds of argument as debates, polemics, dispute and discussion is suggested. The main differences and common features of the genres are established.
\end{abstract}

Keywords: dialogue; genre; argument; debates; polemics; dispute; discussion.

\section{INTRODUCTION}

One of the priorities of modern anthropocentric linguistic studies is consideration from a new paradigm angle of those already partially researched discourse activities that shape their final results, namely in the form of different dialogical genres. In this paper the understanding of close interrelation between man and one's language, communication, discourse, dialogue and its forms or genres is promoted. A human being as a member of an ethnic community is a person that does not only communicate within the frame of this or that dialogical genre but also nominates different interactional activities produced by and in society one dwells in.

Dialogue as an everyday condition of a person's social and biological existence is embodied in various genres the knowledge of the set rules of which is crucial for communication to proceed successfully. Argument (as a genre) is one of those socially important and inherent forms. Through the history of human development, it was converted into a number of its forms or subgenres, the most important of which are polemics, dispute, debates, and discussion. The ethnically specific knowledge of the genres was primarily reflected in their names and afterward in lexicographic sources. The paper suggests a comparative view upon the given genres and subgenres in British and Ukrainian lexicographical tradition which is actually the aim of the suggested research. It's both topical and new as produces some contribution in the field of modern comparative studies.

The typological comparison of the semantic structures of the lexemes that represent subgenres of "argument" in English and Ukrainian has been carried out for the first time in this article. Thus, the novelty of such a type of a research is beyond any doubt. Nevertheless, such nominations were analyzed structurally, semantically, functionally and pragmatically in the works by N. Formanovska [4], I. Saytarli [6], B. Zhumagulova [10], O. Vlasova [9], etc. 


\section{RESEARCH METHODOLOGY}

The scientific investigation has been conducted with the help of the general methods of induction, deduction as well as componential analysis of the meanings of the key words designating different genres of "argument" followed by the descriptive method and contrastive analysis aiming at establishing allomorphic and isomorphic features of this or that subgenre conceptualization within British and Ukrainian ethnic communities.

\section{RESULTS AND DISCUSSION}

The psychological dictionary presents the term argument as follows: an excited emotional verbal exchange between two or more people who differ about something [5]. In an argument interlocutors tend to both defend their own position and eliminate that one of the opponent to establish the only true point of view on the disputable issue. Taking into consideration the other linguistic sources devoted to this subject matter, we define the term under analysis as a genre of dialogue in which the opponent tries to uphold in a wellreasoned manner one's viewpoint on the discussed problem refuting the proponent's proofs $[9,110-$ $112 ; 7,567 ; 4,42]$. Similarly, argument is presented in the British and Ukrainian lexicography practices reflecting the collective ideas of such a type of interaction within these ethnic groups: argument - an exchange of diverging or opposite views, typically a heated or angry one [3] and суперечка - словесне змагання між двома або кількома особами, при якому кожна із сторін обстоює свою думку, правоту [8]. The differences of meanings are disclosed by the semantic components specifying the types of views / thoughts ('diverging or opposite views' and 'свій / правильний') and typical ('typically') for the 'exchange' explication of emotions with negative axiological colouring ('heated or angry') peculiar of English. More than that, the meaning of the Ukrainian lexeme demonstrates several allomorphic features of argument conceptualization as, firstly, 'змагання' (a contest) and, secondly, the number of people mentioned 'між двома або кількома особами' (between two or more persons).

The analysis of the empirical material testifies to the fact that in present-day English argument serves as a synonymic dominant (head) of the synonymic row of such nominative units as debate, dispute, squabble, quarrel, disagreement, clash, brawl, bickering, polemic, contention, disputation, discussion, controversy, altercation, faction, wrangling, etc. [3]; in present-day Ukrainian lexeme суперечка is the head of the synonymic row of such units as сперечання, спір, полеміка, дискусія, незгоди, дебати, диспут, обговорення, суперечки, дебатування, дискутування, еtc. [8].

In this article the focus of our attention is also on the semantic separation of the hyperterms argument / суперечка and hypoterms discussion / дискусія, dispute / диспут, polemics / полеміка, debates / дебати that are in synonymic relations to each other, denoting vital communicative phenomena of British and Ukrainian ethnic societies.

The term polemics (from Greek polemikos - pugnacious, alien) nominates the type of argument which presupposes the confrontation of speakers as well as opposition of different thoughts, ideas, views $[9,111 ; 6,89]$. Functionally argument and polemics unfold around the basic thesis and dialogue partners aim at asserting their own views upon the issue discussed. Polemics as a term is typically used in case the argument tends to have a prolonged character; more than that, it is carried out between people through printed / electronic papers, magazines, journals, social networks or public (i.e. the official format of interaction) oral communication and the positions presented are radically different. Thus, it goes, for instance, about literary or scientific polemics.

The British and Ukrainians conceptualize this type of interaction and reflect it in verbal forms in such a way: a piece of writing or a speech in which a person argues forcefully for or against someone or something [2] / a strong verbal or written attack on someone or something [3] and суперечка в пресі, на зборах, диспуті тощо при обговоренні яких-небудь наукових, політичних, літературних і т. ін. питань [8]. The differential semes in the English meaning are the markers of actual confrontation - '1) verbal / a speech or 2) written / a piece of writing attack' specified by the semantic element 'forcefully' / 'strong'. The Ukrainian meaning contains the components that outline the location of the verbal exchange ('в пресі, на зборах, диспуті') and qualitative characteristics of the issues brought up ('наукових, політичних, літературних').

Polemics is considered to be an uncomfortable type of argument. The reason is that no postulates of Quantity, Quality, Relevancy, Manner and Politeness are observed in this type of dialogue [1], and that's exactly the cause of it being the ex- 
ample of counter-culture of communication [6, 89]. The high emotional tenseness of the interaction leads to understanding it as "a heated argument." That's why the most probable variant of its future development is its conversion into an open confrontation: the opponents hold by their opinions and no synthesis of the views takes place.

Thus, the communicative situation of polemics in both cultures is characterized by the following parameters [10]: 1) the presence of interlocutors: two or more; 2) the character of relations: official; 3) the situation: a contest; 4) the subject: the righteousness of one's own thoughts; 5) the intention: to be the best or better than the opponent; 6) the aim: to defend one's viewpoint and become a winner; 7) the way: persuasion with the help of logical means; 8) the means: presentation of personal arguments and proofs; 9) the social sphere of life: science, literature, politics, media, etc.; 10) prolongation in time (and space).

The difference of polemics from discussion lies in different aims of the dialogical genres. Discussion (from Latin discussio - investigation, review) is a public argument, the aim of which is clarification and collation of different (contrary) points of view in order to find out the truth or for the correct solution of a contradictory issue $[6,89]$.

If the British understand discussion as giving a problem one's careful consideration with the aim to reach a decision or ideas communication ('to reach a decision or to exchange ideas') [3], Ukrainians put an accent not on the performance but rather on its character ('широке, публічне, спірне питання') [8]: cf. the action or process of talking about something in order to reach a decision or to exchange ideas; a conversation or debate about a specific topic and широке публічне обговорення якого-небудь спірного питання; спір, суперечка окремих осіб, співбесідників [8; 3].

Thus, the participants of discussion comparing contrary judgements aspire after coming to one conclusion, finding a basic solution or determining the truth. In contrast to discussion, the aim of polemics is another one: one needs to gain a victory over the opponent, namely to defend and assert one's position through convincing and clear arguments. That's why it's worth mentioning the fact that discussion is a more effective means of persuasion as the interlocutors come to some conclusion on their own $[9,111]$.
Therefore, the communicative situation of discussion is similarly characterized by the following features [10]: 1) the presence of interlocutors: two or more; 2 ) the character of relations: official; 3) the situation: a contest; 4) the subject: the righteousness of one's own thoughts; 5) the intention: the search for the problem solution and compromise; 6) the aim: to reveal or find out the truth; 7) the way: persuasion with the help of logical means; 8) the means: verbal presentation of arguments and proofs; 9) the social sphere of life: science, gatherings, media, etc.; 10) a standing order: time-limits and regulations of speeches of equal participants by the moderator or master of ceremonies.

Debates (French debats, from debatre - to argue) is a kind of argument, an exchange of thoughts that starts on finishing a problematic presentation (report, statement, account at the gathering or conference) $[6,89]$, occasionally covered by mass media.

In English and Ukrainian, the meanings of the lexemes debate and дебати coincide in the archiseme 'дискусія; обговорення питання', cf., debate - a formal discussion on a particular matter in a public meeting or legislative assembly, in which opposing arguments are put forward and which usually ends with a vote [3] and дебати обговорення якого-небудь питання, обмін думками; суперечки, дискусії [8]. If isomorphic semes are 'opposing arguments are put forward' and 'cynеречки, дискусіi', then the allomorphic features are revealed in a number of semantic parameters of the unit debate: 'formal', 'in a public meeting or legislative assembly' and '(ending) in a vote'. Thus, the English semantic structure of the lexeme is more detailed and profound in its "debates description".

The following structural parameters constitute the communicative situation of debates common for the cultures viewed in the paper [10]: 1) the presence of interlocutors: two or more, including the master of ceremonies and audience; 2) the character of relations: official; 3) the situation: an exchange of thoughts as a reaction to the speech produced by one of the participants; 4) the subject: the righteousness of the thought; 5) the intention: to specify and to deepen information on the issue; 6) the aim: the truth and clearance of the point; 7) the way: persuasion with the help of logical means; 8) the means: personal arguments and proofs; 9) the social sphere of life: business, science, politics, media, etc.; 10) a set of rules as 
for the time and speech limits of the equal participants of argument, regulated by the moderator.

Debaters should stick to the suggested ethnically specific rules of conduct, as well as the time limits of different stages of the debates specified by its format and given by the moderator. Debates are conducted either in the presence of audience or not.

Dispute (Latin disputare - to consider, to argue) typically covered by mass media public argument about socially or scientifically vital issues conducted by a wide range of experts $[9,111 ; 6,89]$. In the English dictionaries dispute is revealed as some verbal disagreement: an argument or disagreement, especially an official one between, for example, workers and employers or two countries with a common border [2; 3]. The academic Ukrainian lexicographic source presents dispute as публічний спір на наукову, літературну і $m$. ін. тему (public argument about scientific, literary issue) [8]. Thus, there is a difference in the second functioning archiseme 'disagreement' ('непогодження'), and differential semes of quality ('an official' vs 'публічний; на наукову, літературну тему'). Besides, the British specify the sides of confrontation: 'workers and employers or two countries with a common border'.

Dispute doesn't presuppose the actualization of contrary thoughts. In this dialogue the uncertainty of participants comes out as a result of which versatile thoughts as for the issue discussed are produced and a range of common viewpoints rise. Dispute doesn't lead to practical conclusions. For the complexity of the problem there is no definite final solution, the situation typical for the collective talks of moral, political, scientific, literary, professional character [10].
The communicative situation of dispute in both cultures possesses the following parameters [10]: 1) the presence of interlocutors: two and more; 2) the character of relations: official; 3 ) the situation: a contest; 4) the subject: the idea; 5) the intention: to participate; 6) the aim: to present one's own point of view; 7) the way: to express one's ideas, evaluation; 8) the means: arguments and proofs; 9) the social sphere of life: science, literature, social life, etc.; 10) time limits; 11) the presence of the master of ceremonies and audience; 12) the previous preparation for the event.

\section{CONCLUSIONS}

Argument as a kind of dialogue is a communication process that similarly finds its verbal embodiment in present-day English and Ukrainian languages. Nevertheless, the nominations argument and суперечка fix the understanding of argument as a verbal exchange in the British society of today and a verbal contest in the Ukrainian one; one more existing difference is that the British become excited in argument, the fact reflected in the semes heated or angry (interaction).

The next language specification argument gets in a number of its subgenres. The compared kinds of the genre "argument" generally tend to refer to the cooperative-confrontive type of dialogical communication either spontaneous or organized to solve the problem or presenting the possible ways of its solution. In both cultures argument and polemics are characterized as a means of demonstration of one's position superior to another, whereas truth cognition or problem solution is carried out in discussion, dispute and debates.

\section{REFERENCES}

1. Aristov, S. (2007). Situirovannaya model smeny komunikativnyh roley [Situated model of changing communicative roles]. Retrieved March 10, 2015, from http://studydoc.ru/doc/4091054/situirovannaya-model._-smeny-kommunikativnyh-rolej (in Russian)

[Аристов, С. (2007). Ситуированная модель смены коммуникативных ролей. Актуально на 01.03.2015. URL: http://studydoc.ru/doc/4091054/situirovannaya-model._-smenykommunikativnyh-rolej].

2. Cambridge Dictionary. (2018). Dispute. Retrieved June 16, 2018, from https://dictionary.cambridge.org/dictionary/english/dispute 
3. English Oxford Living Dictionaries. (2018). English Oxford Living Dictionaries. Retrieved June 16, 2018, from https://en.oxforddictionaries.com

4. Formanovskaya, N. (2002). Rechevoe obshchenie: komunikativno-pragmaticheskiy podhod [Verbal communication: communicative and pragmatic approach]. Moscow: Russkiy Yazyk (in Russian) [Формановская, Н. (2002). Речевое общение: коммуникативно-прагматический подход. Москва: Русский язык].

5. Pobirchenko, N. (Ed.). (2007). Psykhologichny slovnyk [Psychological dictionary]. Retrieved from http://elibrary.kubg.edu.ua/id/eprint/5980/3/0_Serhieienkova_IL.pdf (in Ukrainian) [Побірченко, Н. (Ред.). (2007). Психологічний словник. Актуально на 01.09.2018. URL: http://elibrary.kubg.edu.ua/id/eprint/5980/3/0_Serhieienkova_IL.pdf].

6. Saytarli, I. (2007). Kultura mizhosobystisnyh stosunkiv [Culture of interpersonal relationships]. Kyiv: Akademiya (in Ukrainian) [Сайтарли, I. (2007). Культура міжособистісних стосунків. Київ: Академія].

7. Selivanova, O. (2008). Suchasna lingvistika: napryamy ta problemy [Modern Linguistics: Directions and Problems]. Poltava: Dovkillya-K (in Ukrainian)

[Селіванова, О. (2008). Сучасна лінгвістика: напрями та проблеми. Полтава: Довкілля-К].

8. Slovnyk Ukrainskoyi movy. (2018). Slovnyk Ukrainskoyi movy [Dictionary of the Ukrainian language] (11 vol.). Retrieved September 1, 2018, from http://sum.in.ua (in Ukrainian)

[Словник української мови. (2018). Словник украӥнської мови (11 томів). Актуально на 01.09.2018. URL: http://sum.in.ua].

9. Vlasova, E. (2013). Lingvopragmatika ritoricheskogo ideala v situatsii spora [Linguopragmatics rhetorical ideal in a situation of dispute]. In Kommunikativnye aspekty sovremennoy lingvistiki $i$ lingvodidaktiki (pp. 110-116). Volgograd: n. d. (in Russian)

[Власова, Е. (2013). Лингвопрагматика риторического идеала в ситуации спора. В Коммуникативные аспекты современной лингвистики и лингводидактики (с. 110-116). Волгоград: n. d.].

10. Zhumagulava, B. (2013). Osobennosti polemicheskogo diskursa [Features of polemical discourse]. Uspehi sovremennogo estestvoznaniya, 7, 142-145 (in Russian)

[Жумагулова, Б. (2013). Особенности полемического дискурса. Успехи современного естествознания, 7, 142-145]. 